\title{
COMMENTS
}

\section{Private School Voucher Remedies in Education Cases}

\author{
Greg D. Andres $\dagger$
}

Forty-nine state constitutions guarantee the right to an education. ${ }^{1}$ Under these provisions, state legislatures have a duty to provide students with a minimum level of education. Several courts have ruled that their states' school systems have failed to satisfy their constitutional standards, and have ordered legislatures to improve conditions. Nonetheless, most legislatures remain defiant, failing to ensure adequate educational programs.

Education litigation over adequate schooling has resulted in prolonged struggles between the judicial and legislative branches of state governments. Courts have largely left funding decisions to state legislatures due to separation-of-powers concerns. Legislatures, however, have generally been unwilling or unable to provide sufficient funding for local schools. Schools lack proper funding for construction, educational programs, and teacher training. Consequently, students continue to attend constitutionally inadequate public schools.

Frustrated by legislative inaction, student-plaintiffs in two recent suits brought under state constitutional education provisions requested remedies in the form of vouchers, which would allow the students to apply state funds to private school tuition.

$\dagger$ B.A. 1989, University of Notre Dame; J.D. Candidate 1995, The University of Chicago.

1 Mississippi is the only state without an education clause. See William E. Thro, The Role of Language of the State Education Clauses in School Finance Litigation, 79 Educ L Rptr 19 (1993) (collecting state constitutional provisions). 
These cases, Jenkins $v$ Leininger ${ }^{2}$ in Chicago and Arviso $v$ Dawson $^{3}$ in Los Angeles, are currently awaiting review by state appellate courts. ${ }^{4}$ They represent the next phase of education litigation, the remedial stage, and will undoubtedly spark similar litigation across the country. ${ }^{5}$

Under a voucher plan, a student could use the full amount, but no more, of the per-pupil spending in the student's public school district at a private school. If private school tuition exceeds the per-pupil funding allotment, then the student would be required to pay the difference. However, if the public school perpupil spending exceeds the cost of the private school, the student would only receive the private school's tuition. ${ }^{6}$

This Comment argues that private school vouchers provide an effective remedy for violations of students' state education rights under state constitutions. Section I examines the history of education reform litigation, focusing specifically on the reluctance of state courts to take concrete steps to ensure the protection of education rights. Section II argues that tuition vouchers are legally justified and describes the comparative advantages of a voucher remedy. Finally, Section III addresses objections to

2 No 92 CH 05578, slip op ([III] Cir Ct, Cook County, Mar 30, 1993). The trial court dismissed the complaint for failure to state a cause of action, id at 4, and said that the court was, in any case, without power to grant the relief requested, id at 14.

3 No B 077772, slip op ([Cal] Ct App, 2d App Dist, 3d Div, Mar 23, 1995), affg grant of demurrer, No BC 057321, slip op ([Cal] Super Ct, Los Angeles County, June 4, 1993). The trial court sustained the defendants' demurrers, calling the complaint "uncertain," No BC 057321, slip op at 2, and indicating that the court could not grant the relief sought without violating separation of powers and specific provisions of the California Constitution, id at 3-4. The California Court of Appeals affirmed the trial court's decision. No B 077772, slip op.

${ }^{4}$ As of the time of printing, the appellate court in Chicago has not yet set a date for oral argument in Jenkins; the petitioners in Arviso filed a petition for review in the California Supreme Court on May 2, 1995, but no action has been taken.

s The notion of states experimenting to solve challenging social problems has been cited as one of the advantages of a federal system of government. Dissenting in New State Ice Co. $v$ Liebmann, Justice Brandeis wrote, "It is one of the happy incidents of the federal system that a single courageous State may, if its citizens choose, serve as a laboratory; and try novel social and economic experiments without risk to the rest of the country." 285 US 262, 311 (1932) [SEMICOLON IN QUOTE CORRECT]. Successful experiments inevitably spread to surrounding states and may potentially spread nationwide.

6 This Comment does not address the Establishment Clause implications of using state funds in religious schools. For discussion of the Establishment Clause issues involved in state subsidization of private religious schools, see Michael W. McConnell, Multiculturalism, Majoritarianism, and Educational Choice: What Does Our Constitutional Tradition Have to Say?, 1991 U Chi Legal F 125, 139-49; Mark G. Yudof, David L. Kirp, and Betsy Levin, Educational Policy and the Law 130-35 (West, 3d ed 1992); Note, School Choice and the Religion Clauses: The Law and Politics of Public Aid to Private Parochial Schools, 81 Georgetown L J 711 (1993). 
judicially imposed vouchers, focusing on criticisms based on the separation-of-powers and political-question doctrines.

\section{The Evolution of EDUCATton Rights Litigation}

Education reformers first challenged state-run education systems in the federal courts under the United States Constitution in San Antonio Independent School District v Rodriguez. ${ }^{7}$ However, the Supreme Court refused to recognize education as a federal constitutional right. Although this initial effort in the federal courts failed to yield the desired result, it was influential in shaping the strategies and outcomes of subsequent state-law challenges. $^{8}$

\section{A. Success in State Courts}

After Rodriguez, school reform litigants turned to the education clauses of state constitutions and sought redress in state courts. ${ }^{9}$ Plaintiffs sought enforcement of provisions explicitly mandating an "adequate" or "efficient"11 education. Several courts, noting the difficulty in construing the legislative intent behind education clauses, have opted for broad readings, thus granting substantial education rights. Courts have generally interpreted these provisions in a modern context, relying on the notion that state constitutions were "ratified to function as [ ] organic document[s] to govern society and institutions as they evolve through time." ${ }^{\prime 2}$

7411 US 1 (1973). In Rodriguez, a group of school children challenged the Texas school finance system, claiming that it violated the Equal Protection Clause of the Fourteenth Amendment. The Court concluded that the system did not discriminate against a suspect class, id at 28 , and that education was not a fundamental right or liberty protected by the United States Constitution, id at 35. Note, however, that the Court left open the possibility of a constitutional challenge to a state school finance system that "occassioned an absolute denial of educational opportunities to any of [the state's] children." Id at 37.

${ }^{8}$ See generally John J. Gibbons, Like its Lineage, Abbott Is a Product of the Times, NJ L J 19 (June 21, 1990); Note, To Render Them Safe: The Analysis of State Constitutional Provisions in Public School Finance Reform Litigation, 75 Va L Rev 1639, 1653-57 (1989).

9 The expansion of education rights under state constitutions is consistent with the trend toward guaranteeing rights not protected by the federal Constitution by reading them into the individual state constitutions. See generally William J. Brennan, Jr., State Constitutions and the Protection of Individual Rights, 90 Harv L Rev 489 (1977).

${ }_{10}$ See, for example, Ga Const, Art VIII, § 1, I 1; McDaniel v Thomas, $248 \mathrm{Ga} 632$, 285 SE2d 156 (1981).

${ }^{11}$ See, for example, Tex Const, Art VII, § 1; Edgewood Independent School District $v$ Kirby, 777 SW2d 391 (Tex 1989).

${ }_{12}$ Kirby, 777 SW2d at 394. See also Billy D. Walker, Intent of the Framers in the 
The New Jersey Supreme Court pioneered the use of a state constitutional education clause to establish education rights. In Robinson v Cahill ("Robinson I"), decided only thirteen days after the United States Supreme Court's decision in Rodriguez, the New Jersey Supreme Court read the state constitutional provision requiring "a thorough and efficient system of free public schools" as establishing an individually enforceable positive right to a thorough and efficient education. ${ }^{13}$ The court concluded that the state education clause meant what it said: "[It] can have no other import. . . . A system of instruction in any district which is not thorough and efficient falls short of the constitutional command. ${ }^{\text {"14 }}$ Although the court rejected the plaintiff's equal protection claims, it agreed with the trial court that the existing school funding system was unconstitutional because it failed to provide the level of education guaranteed by the state constitution. ${ }^{15}$

Education reformers throughout the United States, influenced by the recognition of education rights in the New Jersey Constitution, focused their energies on state constitutions and state courts. Robinson I generated suits in more than half of the states. ${ }^{16}$ In the $1970 \mathrm{~s}$ and early $1980 \mathrm{~s}$, several of these suits relied on equal protection guarantees in state constitutions, while others relied directly on state education clauses. ${ }^{17}$ Currently, most suits focus on education clauses, ${ }^{18}$ and a number of courts have found state public school systems unconstitutional under these provisions..$^{19}$ For example, the Montana Supreme Court

Education Provisions of the Texas Constitution of 1876, 10 Rev Litig 625, 626-27 (1991).

${ }_{13} 62$ NJ 473, 303 A2d 273, 292 (1973), quoting NJ Const, Art VIII, \& IV, 91.

$14303 \mathrm{~A} 2 \mathrm{~d}$ at 294.

15 Id at 295.

${ }^{16}$ Initially, Robinson I sparked suits in over fifteen states. See William $\mathrm{E}$. Thro, The Third Wave: The Impact of the Montana, Kentucky, and Texas Decisions on the Future of Public School Finance Reform Litigation, 19 J L \& Educ 219, 228-29 n 42 (1990). Later, a new wave of suits began, with cases filed in over half the states. See William E. Thro, Judicial Analysis During the Third Wave of School Finance Litigation: The Massachusetts Decision as a Model, 35 BC L Rev 597, 599 n 5 (1994).

17 See Thro, 19 J L \& Educ at 219, 228-31.

${ }_{18}$ See Thro, 79 Educ L Rptr at 19-23 (cited in note 1). One reason state courts have been averse to granting education rights on equal protection grounds is the potentially explosive effect of a successful suit on analogous claims for housing or other welfare rights. See Thro, $19 \mathrm{~J} \mathrm{~L} \&$ Educ at 241-42. See also Note, $75 \mathrm{Va} \mathrm{L}$ Rev at 1654 (cited in note 8), quoting Robinson I, 303 A2d at 283 ("[T]he equal protection clause may be unmanageable if it is called upon to supply answers in the vast area of human needs.").

${ }_{19}$ See, for example, Abbott $v$ Burke, 136 NJ 444, 643 A2d 575 (1994) (relying on "thorough and efficient" education clause); Rose $v$ Council for Better Education, Inc., 790 SW2d 186 (Ky 1989) (relying on "efficient" education clause); Dupree v Alma School District No. 30, 279 Ark 340, 651 SW2d 90 (1983) (relying on both equal protection and 
struck down the state's public school funding scheme using the state constitution's education clause in Helena Elementary School District No. $1 v$ State. ${ }^{20}$ There, the plaintiffs challenged the 1985-86 Montana school budget, alleging that the scheme created vast disparities in per-pupil funding and deprived students of their education rights. ${ }^{21}$ According to the court, the Montana Constitution requires the state to provide "a system of education which will develop the full educational potential of each person. Equality of educational opportunity is guaranteed to each person of this state."22 The court found that the existing funding system failed to satisfy this mandate. ${ }^{23}$ Similarly, in Edgewood Independent School District $v$ Kirby, the Texas Supreme Court struck down the state's public school financing scheme as unconstitutional under the education clause of the Texas Constitution. ${ }^{24}$

Courts that have adjudicated cases under education clauses have read justiciable standards into the constitutional text. In Rose $v$ Council for Better Education, Inc., for example, the Kentucky Supreme Court held that an "efficient" education, within the meaning of the state constitution, would at a minimum equip students with seven specific categories of knowledge or skills, including written and oral skills, an understanding of governmental processes, and skills to prepare students to work productively. ${ }^{25}$ The Tennessee Supreme Court, in Tennessee Small

"general, suitable, and efficient" education clauses); Seattle School District No. $1 v$ Washington, 90 Wash 2d 476, 585 P2d 71 (1978) (relying on "ample" education clause); Horton $v$ Meskill, 172 Conn 615, 376 A2d 359 (1977) (relying on both equal protection and education clauses).

20236 Mont 44, 769 P2d 684 (1989), modified, 236 Mont 60, 784 P2d 412 (1990).

21 Because the Montana system, like the Texas system at issue in Rodriguez, relied on property taxes, the variations in property values across the state resulted in disparate funding levels for local schools. Some districts held an eight-to-one advantage over others with regard to per-pupil spending. $769 \mathrm{P} 2 \mathrm{~d}$ at 686-88.

22 Id at 689 , quoting Mont Const, Art X, § 1.

$23769 \mathrm{P} 2 \mathrm{~d}$ at 690.

24777 SW2d 391 (Tex 1989). The Texas Supreme Court held that the "state's school financing system is neither financially efficient nor efficient in the sense of providing for a 'general diffusion of knowledge' statewide, and that therefore it violates article VII, section 1 of the Texas Constitution." Id at 397.

25790 SW2d 186 (Ky 1989). The court held that:

[A]n efficient system of education must have as its goal to provide each and every child with at least the seven following capacities: (i) sufficient oral and written communication skills to enable students to function in a complex and rapidly changing civilization; (ii) sufficient knowledge of economic, social, and political systems to enable the student to make informed choices; (iii) sufficient understanding of governmental processes to enable the student to understand the issues that affect his or her community, state, and nation; (iv) sufficient self-knowledge and knowledge of his or her mental and physical wellness; (v) sufficient grounding in the arts to enable each 
School Systems v McWherter, defined the parameters of its state's education clause more generally, requiring a system of education that affords students the opportunity to gain "general knowledge," reasoning powers, and those skills necessary to prepare students for a "mature life."

Rose, Tennessee Small School Systems, Helena Elementary School District No. 1, and Kirby represent the current trend in legal challenges to state education systems. By 1990, education rights had been firmly established as affirmative guarantees under state constitutions-enforceable rights grounded in justiciable standards. In most states, litigation now focuses on the remedies that should be available when those rights have been violated.

\section{B. Rights without Remedies}

Although many courts have recognized state education rights, few have effectively enforced those rights. Consequently, students continue to attend constitutionally deficient schools, ${ }^{27}$ and education litigation lingers on.

Several factors account for judicial restraint in education cases. ${ }^{28}$ First, courts are wary of separation-of-powers principles and often interpret them to preclude judicial action in education,

student to appreciate his or her cultural and historical heritage; (vi) sufficient training or preparation for advanced training in either academic or vocational fields so as to enable each child to choose and pursue life work intelligently; and (vii) sufficient levels of academic or vocational skills to enable public school students to compete favorably with their counterparts in surrounding states, in academics or in the job market.

Id at 212.

${ }_{26} 851$ SW2d 139, 150-51 (1993). The Tennessee Supreme Court said that "the word 'education' [as used in the state constitution education clause,] has a definite meaning and needs no modifiers in order to describe the precise duty imposed upon the legislature." Id at 150. It requires "that the General Assembly shall maintain and support a system of free public schools that provides, at least, the opportunity to acquire general knowledge, develop the powers of reasoning and judgment, and generally prepare students intellectually for a mature life." Id at 150-51.

27 Despite twenty years of reform litigation in New Jersey, The Record, a New Jersey daily newspaper, reports that notwithstanding court rulings, legislative initiatives, and massive spending increases, "it would be hard to find anyone who thinks New Jersey's children are better schooled in 1993 than they were in 1970." John Kolesar, Schools at a Breaking Point... The New Governor Will Face an Education-Funding Mess in the State That's Grown Even Bigger, Record 001 (Jan 2, 1994).

${ }_{28}$ See generally George D. Brown, Binding Advisory Opinions: A Federal Court Perspective on the State School Finance Decisions, 35 BC L Rev 543, 545 (1994) (referring to the courts' refusal to provide remedies in the state education cases as the "phenomenon of merits boldness and remedial deference"). 
traditionally considered a legislative function. ${ }^{29}$ Second, education finance policy involves tax issues, and courts are hesitant to infringe on the legislative taxation power. ${ }^{30}$ Third, majoritarian constraints have limited the role of popularly elected state courts. ${ }^{31}$ Fear of voter backlash over increased taxes compounds the problem by discouraging elected state judges from addressing difficult education reform issues.

The history of education reform litigation in New Jersey illustrates the difficulties in enforcing education rights in the face of judicial deference and legislative inaction. In 1973, the New Jersey Supreme Court held in Robinson $I$ that the state's school finance system was constitutionally inadequate, ${ }^{32}$ but left to the legislature the task of providing a remedy. ${ }^{33}$ Despite numerous judicial deadlines, threats, sanctions, and orders, the New Jersey legislature has still not passed legislation sufficient to ensure students' education rights under the state constitution. ${ }^{34}$ As a result, Kenneth Robinson, the named plaintiff who filed suit when he was nine years old, has reached his thirties, and neither the New Jersey Supreme Court nor the state legislature has yet resolved the problems in the New Jersey educational system. As of July 1994, plaintiffs were still litigating claims similar to those supposedly resolved in Robinson. In Abbott $v$ Burke ("Abbott III"), the New Jersey Supreme Court once again held the state's school finance system unconstitutional, as applied to twenty-eight lowincome school districts. ${ }^{35}$ Not surprisingly, however, while the court used strong rhetoric to describe the deficiencies in the current school program, it shied away from any bold remedial orders. ${ }^{36}$ The court set deadlines for the legislature to correct the

29 See, for example, Danson $v$ Casey, $484 \mathrm{~Pa} 415,399$ A2d 360 (1979) (holding that the legislature was simply in a better position to handle education issues). See also Note, Education Finance Reform Litigation and Separation of Powers: Kentucky Makes Its Contribution, 80 Ky L J 309, 315 (1991-92). See also Note, Unfulfilled Promises: School Finance Remedies and State Courts, 104 Harv L Rev 1072, 1082-83 (1991).

30 See, for example, Board of Education, Levittown Union Free School District $v$ Nyquist, 57 NY2d 27, 439 NE2d 359 (1982). See also Note, 104 Harv L Rev at 1083.

31 See Note, 104 Harv L Rev at 1083-84.

32 See text accompanying notes 13-15.

33303 A2d at 298 .

34 See generally Kolesar, Record at 001 (cited in note 27).

35136 NJ 444, 643 A2d 575 (1994). The court held New Jersey's school finance legislation to be unconstitutional "based on [its] failure to assure parity of regular education expenditures between the special needs districts and the more affluent districts." Id at 576.

${ }^{36}$ In Abbott III, the court cited several supplemental programs, such as preschool programs, health services, and comprehensive guidance and school counseling, which could improve education conditions in the "special needs" school districts. Id at 579. 
disparities. The state currently has until the 1997-98 school year to remedy the problems. ${ }^{37}$

The delays and inaction experienced in New Jersey typify state constitutional challenges to deficient school systems. From Massachusetts to California, courts and legislatures have after decades of struggle still failed to provide adequate remedies for violations of education rights. ${ }^{38}$ Despite judicial decisions, public schools across the country fail to deliver the educational quality state constitutions guarantee.

\section{The Current Challenges: Jenkins $v$ Leininger and Arviso $v$ Dawson}

Unwilling to endure such delays, plaintiffs have recently requested private school vouchers as a remedy for violations of state constitutional education rights. Recently, plaintiffs in two cases, Jenkins $v$ Leininger ${ }^{39}$ in Chicago and Arviso $v$ Dawson $^{40}$ in Los Angeles, have requested vouchers. ${ }^{41}$

However, the court did not mandate implementation of any of these programs, deferring to the legislature and the New Jersey Department of Education. Although the court emphasized that the future of the state and all its citizens would be affected by the quality of education, id at 581, it "decline[d] to enter any orders now," id at 576.

${ }^{37}$ See id at $\mathbf{5 7 7}$.

38 Similar problems have arisen in Massachusetts, Texas, and California, where the education reform process has lingered on for many years after courts initially recognized the deprivation of the student-plaintiffs' constitutional rights to education. In Texas, for example, school finance reform litigation has spanned a twenty-five year period from the 1968 filing of Rodriguez to the 1989 determination that the school finance system violated the state constitution in Kirby. The problems persisted after the Kirby decision as the Texas Supreme Court and state legislature continued to battle over the appropriate remedial action. The Texas Supreme Court has three times invalidated legislative plans to finance the state's schools. On the second occasion, the court set a June 1, 1993, deadline for legislative action. The Texas legislature met this deadline; however, the legislation passed was challenged by the Kirby plaintiffs. In December 1993, a district judge in Texas upheld the legislation as a temporary remedy but mandated that the state further equalize funding by September 1, 1995. See Gardner Selby, School Funding Deadline May Move $U_{p}$, Houston Post A12 (Jan 11, 1994); Comment, Efficient and Suitable Provision for the Texas Public School Finance System: An Impossible Dream?, 46 SMU L Rev 763 (1992).

39 No 92 CH 05578 , slip op at 2.

40 No B 077772, slip op. The opinion in this case names William Dawson, the Acting Superintendent of Public Instruction on June 4, 1993, as defendant, while the complaint and briefs name Bill Honig, the Superintendent of Public Instruction.

${ }^{41}$ In a third case, Rivarde $v$ Missouri, 930 F2d 641 (8th Cir 1991), black students sought vouchers to transfer from segregated schools in Kansas City. The Eighth Circuit held that the plaintiffs could not bring a new action based on a desegregation order in another pending case and mandated that they instead intervene in the pending suit. See Casenote, Jenkins v. Missouri: School Choice as a Method for Desegregating an Inner-City School District, 81 Cal L Rev 1029 (1993). 
In both Jenkins and Arviso, the plaintiffs ${ }^{42}$ sought vouchers to remedy violations of their education rights under their respective state constitutions. ${ }^{43}$ They argued that their local public schools did not provide them with adequate educational opportunities. ${ }^{44}$ In both school districts, crime in the schools was pervasive, dropout rates were significantly higher than the state average, and test scores were dismal ${ }^{45}$ Accordingly, parents wished to transfer their children to neighborhood private schools, where better educational opportunities existed, and they requested vouchers for tuition costs. ${ }^{46}$

Both suits were unsuccessful at the trial court level and are currently being appealed. In 1993, the Cook County Circuit Court dismissed the plaintiffs' suit in Jenkins for failure to state a cause of action, ${ }^{47}$ adding in dicta that even if the plaintiffs had established that Chicago's public schools were constitutionally inadequate, policy considerations precluded the court from granting private school vouchers as a remedy. The court declared that the plaintiffs' voucher request presented 'essentially a political question that should be decided in the public arena. Courts must exercise judicial restraint. Courts should not attempt to decide questions that rightfully belong to the legislature. ${ }^{48}$

The same year, the Los Angeles Superior Court denied relief in Arviso, calling the plaintiffs' claim "uncertain." ${ }^{\prime 9}$ The court

42 The plaintiffs in Jenkins are one hundred low-income parents and children in the Chicago school system. See Jenkins, No $92 \mathrm{CH} 05578$, slip op at 2. In Arviso, plaintiffs are forty-seven low-income parents and children in the Los Angeles public school system. See Appellants' Brief at 2, Arviso, No B 077772 (on file with U Chi L Rev).

43 The Mlinois Constitution guarantees "an efficient system of high quality public educational institutions and services." Ill Const, Art X, $\S 1$.

The California Constitution provides that "the Legislature shall encourage by all suitable means the promotion of intellectual, scientific, moral, and agricultural improvement." Cal Const, Art IX, § 1.

41 In Jenkins, the plaintiffs' complaint cited the following statistical data as evidence of the schools' poor conditions: 70 percent of Chicago school students score below the national norm on standardized basic skills tests; graduation rates are below 50 percent, significantly lower than the state average; and prospects for college are considered low. Complaint at 12-14, Jenkins, No $92 \mathrm{CH} 05578$ (on file with U Chi L Rev). In Arviso, the plaintiffs asserted that the schools they attend rank at or near the bottom by all measures: test scores are low, as are graduation rates. See Amended Complaint at 24-29, $36-$ 37, Arviso, No BC 057321 (on file with U Chi L Rev).

45 Appellants' Brief at 4-6, Arviso, No B 077772; Appellants' Brief at 6-7, Jenkins, No $92 \mathrm{CH} 05578$ (on file with U Chi I Rev).

${ }_{46}$ See Appellants' Brief at 7-8, Arviso, No B 077772; Jenkins, No 92 CH 05578, slip op at 2.

47 See Jenkins, No $92 \mathrm{CH} 05578$, slip op at 4 .

48 Id at 14.

49 See Arviso, No BC 057321, slip op at 2. 
also reasoned that the allocation of school funds and, more generally, the fiscal decisions of the state were legislative tasks. Consequently, the court rejected the request for a voucher remedy, concluding that it was prevented from ordering this relief by the separation-of-powers and political-question doctrines, and the California Court of Appeals affirmed..$^{50}$

\section{VOUCHERS AS EQUITABLE REMEDIES}

Students deprived of their state constitutional right to a quality education have a right to a remedy. This Section sets forth the reasons why courts should mandate the issuance of vouchers as a remedy for a constitutionally inadequate education.

\section{A. The Right to a Remedy}

Both common law principles and state constitutional law mandate enforcement of education rights. Most state constitutions contain remedy guarantee clauses that require states to redress constitutional violations. ${ }^{51}$ State courts are obligated to protect constitutional rights, including education rights, and remedy guarantee clauses require the courts to act. Furthermore, armed with equitable powers, courts maintain the power to fashion novel and creative remedies for violations of these rights. Thus, both remedy guarantee clauses and equitable powers enable courts to fashion adequate remedies.

First, a majority of state constitutions contain remedy guarantee clauses that, when applied to violations of constitutional education rights, give state courts ample authority to fashion remedies. ${ }^{52}$ For example, the Illinois Constitution states:

Every person shall find a certain remedy in the laws for all injuries and wrongs which he receives to his person, privacy, property, or reputation. He shall obtain justice by law, freely, completely and promptly. ${ }^{53}$

so Id at 3, affd, No B 077772 , slip op. The trial court also stated that relief in the form of vouchers would violate the California Constitution. No BC 057321, slip op at 3-4.

51 For a discussion of courts' remedial obligations, see Paul Gewirtz, Remedies and Resistance, 92 Yale L J 585 (1983).

52 At least thirty-eight state constitutions have remedy guarantee clauses. See David Schuman, The Right to a Remedy, 65 Temple L Rev 1197, 1201 n 25 (1992) (collecting state constitutional provisions).

53 Ill Const, Art I, § 12. 
These provisions codify the common law maxim $u b i$ jus, ibi remedium-where there is a right, there is a remedy. ${ }^{54}$

While these provisions have generally been applied to tort and contract actions, they reach all constitutional and statutory rights. ${ }^{55}$ State constitutional education clauses create positive rights to a quality education, and the remedy guarantee clauses impose on courts a duty to redress violations of these rights. ${ }^{56}$ If vouchers are an appropriate remedy for educational inadequacies, then these remedy guarantee clauses authorize courts to grant such a remedy.

Second, state courts possess the power in equity to fashion and issue private school vouchers. Most state courts of general jurisdiction, like their federal counterparts, are empowered to sit in equity by constitutional grants. ${ }^{57}$ Their equitable powers are

st See Black's Law Dictionary 1520 (West, 6th ed 1990). See also R.L. v Bedell, 1994 W Va LEXIS 219 (extending remedy guarantee clause to citizen's right to seek grand jury indictment); Neher $v$ Chartier, 319 Or 417, 879 P2d 156 (1994) (holding that law immunizing public bodies and officials from liability for tort or wrongful death suits for those covered by worker's compensation violated the Oregon Constitution's remedy guarantee clause).

${ }^{55}$ See Note, The Right of Access to Civil Courts under State Constitutional Law: An Impediment to Modern Reforms, or a Receptacle of Important Substantive and Procedural Rights?, 13 Rutgers L J 399, 425 (1982) ("Constitutional provisions guaranteeing access to state civil courts should not be dismissed as historical relics that serve more as impediments to change than as vibrant statements of cherished rights important in many different contexts."); Burgess $v$ Eli Lilly and Co., 66 Ohio St 3d 59, 609 NE2d 140 (1993) (holding statute of limitations on right to recovery violates right-to-remedy clause of state constitution).

${ }^{56}$ See Robinson v Cahill, 69 NJ 133, 351 A2d 713, 720 (1975) ("Robinson IV") (holding that if the right to education is a fundamental constitutional right, the court is obliged to remedy violations of that right). See also Seattle School District No. 1 of King County $v$ Washington, 90 Wash 2d 476, 585 P2d 71, 87 (1978) ("Once it has been determined that the court has the power or the duty to construe or interpret words or phrases in the constitution and to give them meaning and effect by construction, it becomes a judicial issue rather than a matter to be left to legislative discretion.").

${ }_{57}$ The states began to merge law and equity in their judicial systems as early as 1848, beginning with the adoption of the Field Code in New York. The Federal Rules of Civil Procedure adopted the merger in 1938. See Dan B. Dobbs, 1 Law of Remedies $\S 2.6$ at 148 (West, 2d ed 1993); FRCP 1, 2.

Four states still have separate courts for law and equity: Arkansas, Delaware, Mississippi, and Tennessee. Ark Stat Ann \$§ 16-57-101 to 103 (1987); Del Const, Art IV, $\S 1$; 10 Del Code Ann $\S \S 341-42,541$ (1975); Miss Const, Art 6, §§ 156, 157, 159; Miss Code Ann §§ 9-5-81, 9-7-81 (1972); Tenn Code Ann §§ 16-10-101, 16-11-101 (1980).

State constitutions generally grant state courts the power to sit in equity. See, for example, $K N$ Energy, Inc. $v$ City of Scottsbluff, 233 Neb 644, 447 NW2d 227 (1989); Nethercutt v Pulaski County Special School District, 248 Ark 143, 450 SW2d 777 (1970). The New Jersey Constitution provides a useful model of this jurisdictional grant to state courts. 
broad and flexible, constrained only by judicial discretion, pragmatism, public policy, and the law. ${ }^{58}$ The use of vouchers that this Comment proposes would function as an equitable remedy devised to guarantee an affirmative right where there is no adequate legal remedy.

Equity seeks to provide relief that is necessary but unavailable in legal remedies. A court's equitable powers are invoked when a plaintiff can show that no adequate legal remedy is available. To qualify as a legal remedy, the relief must be "clear, complete and as practical and efficient" as the equitable remedy. ${ }^{59}$ This is a difficult standard to meet and rarely precludes equitable remedies. ${ }^{60}$ Equity power enables courts to fashion individual and unique remedies to challenging problems ${ }^{61}$ such as those

Subject to the rules of the Supreme Court, the Law Division and the Chancery Division shall exercise the powers and functions of the other division when the ends of justice so require, and legal and equitable relief shall be granted in any cause so that all matters in controversy between the parties may be completely determined.

NJ Const, Art VI, § III, $\mathbb{T} 4$.

${ }^{58}$ See Michigan Salt Works $v$ Baird, 173 Mich 655, 139 NW 1030, 1032 (1913) ("exercise of [equitable powers] jurisdiction rests in the sound discretion of the court"); Hall $v$ Wood, 443 S2d 834, 842-43 (Miss 1983) (equitable powers are broad and flexible). See also Kent Roach, The Limits of Corrective Justice and the Potential of Equity in Constitutional Remedies, 33 Ariz L Rev 859, 859-60 (1991) ("In its method, which stresses flexibility and the appropriateness of pragmatic solutions, equity is [ ] characterized by a relative lack of concern for rules.").

${ }_{59}$ Levitt Homes Inc. v Old Farm Homeowners' Association, $111 \mathrm{ml}$ App 3d 300, 444 NE2d 194, 204 (1982). See also In re C.B., F.C., J.J., and L.K., 147 Vt 378, 518 A2d 366, 369 (1986); D.C. Trautman Co. v Fargo Excavating Co., Inc., 380 NW2d 644, 645-46 (ND 1986).

60 The "irreparable injury rule" holds that when legal remedies are "inadequate" a court is free to invoke its equitable powers. Although commentators doubt the consistency and validity of this rule, its supporters and critics alike note that the showing necessary to establish that a legal remedy is adequate is so difficult that equitable remedies are almost always an option. See Douglas Laycock, The Death of the Irreparable Injury Rule, 103 Harv L Rev 687, 701-02 (1990); Gene R. Shreve, Federal Injunctions and the Public Interest, 51 Geo Wash L Rev 382, 402-03 (1983).

61 See, for example, Fisher $v$ Health Insurance Plan of Greater New York, 67 Misc 2d 674,324 NYS2d 732, 737 (1971) (equity jurisdiction arises out of the court's inability to adapt judgments to the particular circumstances of a case due to the inflexibility of legal rules). The Supreme Judicial Court of Maine characterized equity in this way:

[E]quity has always preserved the elements of flexibility and expansiveness so that new remedies may be invented or old ones modified in order to meet the requirements of every case and to satisfy the needs of a progressive social condition. In other words, the plastic remedies of equity are molded to the needs of justice and are employed to protect the equities of all parties, and the flexibility of equitable jurisdiction permits innovation in remedies to meet all varieties of circumstances which may arise in any case.

Levasseur v Dubuc, 229 A2d 201, 204 (Me 1967), citing 27 Am Jur 2d Equity § 103. 
presented in the education cases.

State courts have traditionally relied on the flexibility of their equitable powers to safeguard individual rights. Courts are particularly receptive to granting equitable remedies in civil rights cases, where legal money damage remedies are often inadequate. ${ }^{62}$ In Butt $v$ California, for example, the California Supreme Court employed its equitable powers to protect students' education rights against the threat of an early school closure. ${ }^{63}$ The court affirmed a decision that authorized the takeover of a local school district by the state in order to remedy financial mismanagement that threatened to shorten the school year. ${ }^{64}$ Similarly, state courts have fashioned equitable remedies to protect housing ${ }^{65}$ and voting rights; ${ }^{66}$ to secure adequate administrative hearings, ${ }^{67}$ integrated public facilities, ${ }^{68}$ and competent mental care; ${ }^{69}$ and to guarantee the freedom of speech $^{70}$ and of religion. ${ }^{71}$

62 See Laycock, 103 Harv L Rev at 707.09 (cited in note 60) ("The principle that damages are an inadequate remedy for the loss of something irreplaceable is not limited to unique or scarce tangible property. The principle also applies to intangible rights that cannot be bought or sold in any market. This is why injunctions are the standard remedy in civil rights and environmental litigation.") (footnotes omitted).

63 Cal 4th 668, 15 Cal Rptr 2d 480 (1992).

64 Id at 497-500.

${ }_{65}$ See Southern Burlington County NAACP v Township of Mount Laurel, 92 NJ 158, 456 A2d 390 (1983) (devising equitable remedies to protect constitutional due process rights to low-income housing); Perez $v$ Boston Housing Authority, 379 Mass 703, 400 NE2d 1231 (1980) (using equitable powers to appoint a receiver for Boston Housing Authority).

${ }^{66}$ See O'Connors $v$ Helfgott, 481 A2d 388, 394 (RI 1984) (ordering the redistribution of voting powers on a local school committee in order to protect the "one-person, one-vote principle"). See also Laycock, 103 Harv L Rev at 708 \& n 102 (cited in note 60).

67 See Hein $v$ Marts, 295 NW2d 167 (SD 1980) (ordering the denial of a water permit that had been granted without an adequate hearing). See also Laycock, 103 Harv L Rev at $708 \& \mathrm{n} 103$ (cited in note 60 ).

${ }_{68}$ See Everett $v$ Harron, $380 \mathrm{~Pa} 123,110$ A2d 383 (1955) (upholding order that recreation area abandon its racially discriminatory admittance policies). See also Laycock, 103 Harv L Rev at 708 \& n 104 (cited in note 60).

${ }^{69}$ See O'Sullivan $v$ Secretary of Human Services, 402 Mass 190, 521 NE2d 997 (1988) (upholding order that hospital change its practices with respect to the seclusion and restraint of patients). See also Laycock, 103 Harv L Rev at 709 \& n 117 (cited in note 60).

${ }^{70}$ See Kenyon v City of Chicopee, 320 Mass 528, 70 NE2d 241 (1946) (holding that the plaintiffs could obtain an injunction against the enforcement of a city ordinance that prohibited handbilling). See also Laycock, 103 Harv L Rev at 708 \& $n 106$ (cited in note 60).

${ }^{71}$ See Lily of the Valley Spiritual Church $v$ Sims, 169 Il App 3d 624, 523 NE2d 999 (1988) (ordering preliminary injunction to protect right to religious freedom). See also Laycock, 103 Harv L Rev at 708 \& n 107 (cited in note 60). 


\section{B. Vouchers Are an Effective and Efficient Remedy}

Vouchers provide a quick, effective, and narrowly tailored remedy for violations of education rights. They enable courts to remedy constitutional violations without becoming involved in difficult policy decisions. While vouchers appear to be an innovative and aggressive solution, they are actually in many ways the least intrusive alternative available to remedy the deprivation of education rights.

\section{Vouchers provide a timely remedy.}

Vouchers are first and foremost an effective remedy given their timely impact. With vouchers, children transfer immediately from inadequate public schools to superior private schools. ${ }^{72}$ As noted above, legislatures often wait decades before adequately responding to unconstitutional school conditions, and courts have proven equally unwilling to provide a solution. ${ }^{73}$ These delays have potentially devastating effects on students' educational development. Education lawsuits filed when students enter kindergarten often remain unresolved by the time those students graduate from high school. ${ }^{74}$ Thirteen years of legislative inaction results in thirteen years of ineffective education.

Because private school vouchers would transfer students into quality schools immediately, they would afford these students an opportunity to learn vital skills at the necessary time. Students must learn certain skills at specific points in their development. Second grade students in substandard public schools who fail to adequately learn basic reading, writing, and arithmetic skills develop into troubled third, fourth, and fifth graders. The problem compounds as students who lack the proper grounding in basic skills progress through the system. When students are forced to attend substandard public schools, their fate is in many respects predetermined because "the kind of education [the stu-

72 Catholic schools, for example, have continuously outperformed public schools despite "low salaries, high faculty turnover and average teaching." See Peter Steinfels, Why Catholic Schools Succeed: A Community of Shared Values, NY Times A32 (Apr 17, 1994). See also Note, State Constitutional Restraints on the Privatization of Education, 72 BU L Rev 381, 386 (1992), citing a study published in James S. Coleman, Thomas Hoffer, and Sally Kilgore, High School Achievement: Public, Catholic, and Private Schools Compared 219-23 (Basic Books, 1982), which found that "private school students fared better academically ... than their peers who attended public schools."

${ }^{73}$ See Section I.B.

74 See, for example, Lisa Davis, What Reform? Class of 2000 Unlikely to See Many Changes, Phoenix Gazette A6 (Apr 22, 1994). 
dent] gets there shapes his future progress not only in school but in society in general." ${ }^{\text {n5 }}$

\section{Precedent for a voucher remedy.}

There is strong precedent for using vouchers in education cases. In analogous situations involving mental hospitals, prisons, and low-income housing, courts have instituted creative equitable remedies, including vouchers, to correct constitutional violations. ${ }^{76}$

For example, courts have demanded that handicapped students be educated at public expense in private schools of their parents' choosing. In 1993, the United States Supreme Court in Florence County School District Four $v$ Carter unanimously affirmed a decision ordering a school district to reimburse the parents of a disabled child for the cost of educating their child in a private school. ${ }^{77}$ The Court upheld the plaintiffs' right to an education under the Individuals with Disabilities Education Act. ${ }^{78}$ Under this federal statute, state officials are required to provide a "free appropriate public education" for handicapped children, ${ }^{79}$ and may send children to private schools at no cost to the children's parents if local schools are unable to accommodate them. ${ }^{80}$ In Carter, the Court held that because the local school district did not provide the student with the special services required by her disability, her parents could enroll her in a private school and demand reimbursement. ${ }^{81}$

While the plaintiffs in Carter relied on a federal statute to secure a voucher-like remedy, the language of the statute, guaranteeing a "free appropriate public education," mirrors that of many state constitutional education clauses. ${ }^{82}$ Under the federal statute, parents may seek judicial consideration of a student's educational plan to determine if the curriculum provided is free

${ }^{75}$ See Hobson $v$ Hansen, 269 F Supp 401, 473 (D DC 1967).

${ }^{76}$ See Theodore Eisenberg and Stephen C. Yeazell, The Ordinary and the Extraordinary in Institutional Litigation, 93 Harv L Rev 465, 489 (1980) ("It can scarcely be said that a modern exercise of equitable power to correct conditions in a prison, hospital, or school is a new-fangled addition to the judicial arsenal.").

$\pi 114 \mathrm{~S} \mathrm{Ct} 361,361-63$ (1993).

${ }^{78}$ Id. See 20 USC $\$ 1400$ et seq (1988 \& Supp 1990).

7920 USC § 1412(1). See also 20 USC \& 1401(a)(18) (defining "free appropriate public education").

${ }^{80} 20$ USC § 1413(a)(4)(B)(i).

${ }^{81}$ See $114 \mathrm{~S} \mathrm{Ct}$ at 364-65.

${ }^{82}$ See text accompanying notes 10-11. 
and appropriate. ${ }^{83}$ Judges are given the power to place students in private schools when public schools fail to provide the necessary level of education. In addition to statutorily authorized remedies, judges have similarly broad equitable powers when faced with the violation of constitutional education rights.

The Supreme Court's decision in Carter is the latest in a series of state and federal cases in which courts have vindicated education rights with state funds in the form of voucher-like remedies. The Supreme Court also approved the funding of a sign language interpreter for a deaf student in Zobrest $v$ Catalina Foothills School District. ${ }^{84}$ Courts have effectuated the rights of blind ${ }^{85}$ non-English-speaking, ${ }^{86}$ dyslexic, ${ }^{87}$ and disabled students $^{88}$ as well. In each of these cases, a court recognized the local schools' inability to provide a proper education and ordered them to fund private school tuition. In each instance, these voucher-like remedies presented the least intrusive remedy available to the court. Vouchers ensured the plaintiffs' rights without involving the courts in prolonged debates on education policy.

State courts, like their federal counterparts, have also issued voucher-like remedies to address the deprivation of education rights. In Byrnes $v$ Riles, a California court ordered the state to reimburse the parents of a language-handicapped student after they had placed him in a private school. ${ }^{89}$ Similarly, in Walker $v$ Cronin, an Illinois court allowed the mother of a handicapped student to recover the cost of placing her child in a private school. ${ }^{90}$ In these cases, as in the federal cases, the courts re-

8320 USC § 1415(e).

\& 113 S Ct 2462 (1993).

${ }^{85}$ See Witters $v$ Washington Department of Services for the Blind, 474 US 481 (1986) (use of public education funds for a blind student at a Bible College is constitutionally permissible).

${ }_{86}$ See Castaneda v Pickard, 648 F2d 989 (5th Cir 1981) (authorizing use of broad remedial powers to secure the education rights of a Spanish-speaking student by, for example, mandating greater teacher training and improved measures for monitoring progress of students); United States v Texas, 506 F Supp 405 (E D Tex 1981), revd on other grounds, 680 F2d 356 (5th Cir 1982) (exercising remedial powers to correct school discrimination against Mexican-American students by mandating a bilingual education program).

${ }_{87}$ Straube v Florida Union Free School District, 801 F Supp 1164 (S D NY 1992) (ordering the state to provide improved educational opportunities to a dyslexic student).

${ }^{83}$ School Committee of Burlington v Department of Education of Massachusetts, 471 US 359 (1985) (holding that municipality had to reimburse parents who moved disabled child to private school after public school failed to provide adequate educational opportunities).

89 157 Cal App 3d 1170, 204 Cal Rptr 100, 105 (1984).

${ }_{90} 107 \mathrm{Ml}$ App 3d 1053, 438 NE2d 582, 586 (1982). 
solved education disputes, yet escaped difficult policy determinations by resorting to voucher-like remedies to effectuate education rights.

The courts' jurisprudence with regard to handicapped students is equally applicable to the plight of students who attend substandard public schools in inner cities and elsewhere. While vouchers issued to students in deficient schools would, due to the number of students involved, place a significantly more serious strain on education funds than vouchers issued to handicapped students, the basis for relief would remain the same. Just as the handicapped student is deprived of an adequate education because of insufficient facilities to accomodate his particular physical or learning disability, so too students at substandard schools are deprived of their constitutional right to an adequate education because of ineffective public schools. Courts granting voucher-like remedies to handicapped students would be equally justified in granting other students vouchers that similarly ensure constitutionally mandated minimal educational opportunities.

3. Vouchers avoid intrusive judicial action.

Vouchers provide the best remedy to education disputes because they effectively avoid judicial management of education policy. By issuing vouchers, a court transfers students from constitutionally inadequate public schools to accredited private schools that provide a constitutionally sufficient education. Because these private schools already provide satisfactory instruction, a court does not have to dictate the details of education reform to protect the students' education rights.

Alternative solutions require significant judicial tinkering with the present public school system. Judicially created institutional remedies are often criticized because they involve matters beyond the expertise of the judiciary, requiring policy decisions for which courts are poorly designed..$^{1}$ So far, at least one court has tried unsuccessfully to second-guess school funding, facility, and curriculum decisions.

Jenkins $v$ Missouri ${ }^{92}$ highlights the difficulties with judicial-

${ }^{91}$ See generally Abram Chayes, The Role of the Judge in Public Law Litigation, 89 Harv L Rev 1281 (1976); Board of Education of the Hendrick Hudson School District $v$ Rowley, 458 US 176, 208 (1982).

${ }^{92} 639$ F Supp 19 (W D Mo 1985), aff'd as modified, 807 F2d 657 (8th Cir 1986). While the Jenkins court faced desegregation issues, the court's involvement in the restruc- 
ly mandated education plans in which courts institute spending and curriculum programs in an effort to improve educational opportunities. In that case, the court devised a massive reorganization plan. Among its actions, the court enjoined a statutory tax rollback, mandated staff hiring, supervised the planning and construction of new facilities, and collaborated in rewriting the curriculum. ${ }^{93}$ However, despite the court's extensive efforts to improve educational opportunity and achievement, there has been little progress in integrating schools, raising test scores, or lowering dropout rates. ${ }^{94}$

In addition to school management, courts have previously been involved in the takeover of prisons, mental hospitals, and local government entities. ${ }^{95}$ This aggressive judicial action, however, often embroils courts in policy decisions traditionally reserved for the executive or legislative branches. Commentators have criticized the courts' roles in these cases, questioning whether courts have the authority or technical expertise to manage such institutions. ${ }^{96}$

Court-ordered vouchers would avoid intrusive judicial action in state education systems. Vouchers do not replace school administrators with judges. Unlike alternative remedies, under which courts take over schools or recommend legislative initiatives, vouchers do not require judicial decisions about per-pupil funding, busing, student-to-teacher ratios, curriculum content, or construction plans. Vouchers aim only to protect the plaintiffs' constitutional rights; they avoid complex policy decisions and reserve for the legislature questions of school accreditation and standards. Clearly the "courts are not school boards or legislatures, and are ill-equipped to determine the 'necessity' of discrete aspects of a State's program of compulsory education." ${ }^{\prime \prime 7}$

turing of the Missouri schools illustrates the problems involved in intrusive judicial management of the education system.

${ }^{93}$ Id at 26-46.

${ }^{94}$ Despite efforts to create "the best school system money could buy" by infusing $\$ 1.3$ billion in additional spending, the results in the Missouri public school system have been dismal. See American Survey: The Cash Street Kids, Economist 23, 24-25 (Aug 28, 1993) ("So far, however, all this lavish expenditure has produced few of the desired results.").

${ }_{95}$ Robert F. Nagel, Separation of Powers and the Scope of Federal Equitable Remedies, 30 Stan L Rev 661, 661-62 (1978) (citing Morgan v Sproat, 432 F Supp 1130 (S D Miss 1977) (state prison); Wyatt v Stickney, 344 F Supp 373 (M D Ala 1972), aff'd in part, Wyatt $v$ Aderholt, 503 F2d 1305 (5th Cir 1974) (state mental health system); Bolden v City of Mobile, 423 F Supp 384 (S D Ala 1976) (city government)).

${ }^{96}$ See generally Nagel, 30 Stan L Rev 661 (authority); Chayes, 89 Harv L Rev 1281 (expertise); Rowley, 458 US at 208.

${ }_{97}$ Wisconsin $v$ Yoder, 406 US 205, 235 (1972). See also Rowley, 458 US at 208, citing 
4. Possible school closings and other voucher objections.

Many school officials oppose private school vouchers, arguing that vouchers will destroy public education by diverting both students and funds out of public schools. These officials argue that once a student is awarded a voucher, a precedent will be set that allows all students in the "condemned" school to obtain vouchers, thus destroying local public schools. Additionally, officials claim that vouchers undercut educational development by siphoning off needed funding, further aggravating the already difficult problems faced by public schools. ${ }^{98}$. In essence, voucher opponents argue that public funding for students must be kept in the system if public schools are to survive. These objections do not, however, justify the denial of students' affirmative constitutional rights.

a) Constitutionally guaranteed education rights. The objections to vouchers are mitigated when weighed against the individual students' constitutional rights to adequate educations. Courts have recognized individual students' valid constitutional claims to adequate educational opportunities. Fears that these claims will alter the status quo in education do not justify the denial of these rights. Many public schools have failed to meet their duty, thus justifying judicial action to provide adequate educational opportunities at alternative facilities. To deny voucher remedies because of the harmful effects such a solution might have on the already deficient public schools ignores the states' constitutional obligations. At the heart of the dispute is the students' constitutional education rights, not the right of the schools to exist. ${ }^{99}$ Just as the courts dismantled unconstitutionally segregated schools, so too the courts must act to eliminate unconstitutionally deficient schools.

\footnotetext{
Rodriguez, 411 US at 42 ('[C]ourts lack the 'specialized knowledge and experience' necessary to resolve 'persistent and difficult' questions of educational policy."); Milliken $v$ Bradley, 418 US 717, 742-43 (1974) (noting the logistical problems involved in large-scale school busing, as well as the difficulties in financing and operating a new, judicially created school system).

${ }^{38}$ See Steven K. Green, The Legal Argument Against Private School Choice, 62 U Cin L Rev 37, 39 (1993); Augustus F. Hawkins, Becoming Preeminent in Education: America's Greatest Challenge, 14 Harv J L \& Pub Policy 367, 382-83 (1991).

99 That a public school or schools should be closed for failing to properly educate its students is not a new concept. Education reformers have long lobbied for alternative education systems. See John E. Coons and Stephen D. Sugarman, Education by Choice: The Case for Family Control 23 (California, 1978) (describing radical changes proposed in the 1950s and 1960s).
} 
The issuance of vouchers to a group of student-plaintiffs in one school does not ensure such a remedy for all students in that school system. Under the proposed voucher plan, public schools that provide good educational opportunities will continue to thrive; it is only those schools that fail to provide adequate opportunities that will be affected by vouchers. Arguably, competition for students will make the good schools even better because they will no longer have a guaranteed enrollment. ${ }^{100}$

Furthermore, school vouchers will not necessarily drain public school funds; in fact, school administrators might actually have more money to spend on the students who remain. Vouchers could raise a public school's per-pupil funding because private school tuition is often less costly than public school per-pupil spending. In Chicago, for example, public schools receive approximately $\$ 5,600$ per pupil, while private school tuition is as low as $\$ 2,500 .{ }^{101}$ Under a voucher system, the school district from which a voucher participant withdraws would not lose the funding that exceeds private school tuition. ${ }^{102}$ Consequently, public school systems will not necessarily be drained of funds.

However, even if school closure is a possible result of voucher remedies, the rationale for keeping the potentially affected schools open is unclear given their inability to sustain minimal levels of educational proficiency. Voucher opponents fight for the institutional rights of schools; state constitutions, however, grant education rights to individuals. Public schools exist to provide students with their constitutionally guaranteed rights to education. To the extent that schools fail to do this, they serve no purpose. ${ }^{103}$ Schools that infringe upon students' rights to education rather than foster them should be closed. In short, the constitutional rights of the students trump the rights of schools.

Furthermore, it is important to keep in mind that any voucher remedy is merely a temporary remedy to a much larger problem. Ideally, judicial activism will spark legislative reform. Thus,

100 See Clint Bolick, Puerto Rico: Leading the Way in School Choice, Wall St J A11 (Jan 14, 1994).

101 See Plaintiff's Appellate Brief at 4, Jenkins, No $92 \mathrm{CH} 05578$ (on file with U Chi L Rev) (noting per-capita spending on public school students in Chicago); Voucher Plan Goes to Court, Christian Sci Monitor 12 (Sept 14, 1992) (noting options available in private schools for $\$ 2,500$ per year).

102 See text accompanying note 6.

103 Many public schools are considered to be failing. See Thomas G. Tancredo, The Case For Vouchers, 71 Educ L Rptr 593, 593-94 (1992) (noting that despite consistent signs of failure and poor results, public schools are perpetuated rather than shut down); James A. Peyser, School Choice: When, Not If, 35 BC L Rev 619, 626-27 (1994). 
if the issuance of vouchers to a significant portion of a school population does indeed threaten school closure or even the complete breakdown of the public school system, the legislature always has the option to act, passing aggressive reform plans to bring the state's school system in line with the necessary constitutional standards, and thereby foregoing the need for vouchers.

b) Policy concerns: Limited voucher remedy. In order to address concerns that judicially imposed vouchers would result in massive school closures, courts could alternatively grant vouchers to only those plaintiffs who can meet certain limiting criteria. While this alternative might fail to secure the constitutional rights of every student, a limited voucher remedy would at least improve the quality of education for students who opt out of the public schools with vouchers. Under this more restrictive plan, courts would only allow students in certain public schools to use state per-pupil funding to attend constitutionally acceptable private schools. While such a limited voucher remedy undermines to a certain degree the rights of the students excluded from the voucher program, this system is nonetheless preferable to the present system.

Vouchers could be limited in a variety of ways. For example, in addition to establishing the unconstitutionality of their public school, students might be required to show one or all of the following to qualify for a voucher: (1) that their families cannot afford private school tuition; (2) that their current public school fails to provide educational opportunities similar to those available at other schools in the district; and (3) that the private school they wish to attend has space to accommodate them. Alternatively, vouchers might be strictly limited to, say, the bottom 5 percent of students, or the top 5 percent. Such a limited voucher remedy is not open ended, and would not likely threaten to dismantle the public school system.

Courts could give specific content to these standards. The showings for wealth and school standards, for example, might be based on percentages or welfare cutoffs. Similarly, a court might determine that only those students whose families are below the poverty line and who attend schools ranked in the bottom 20 percent of the district are eligible for vouchers. Such a voucher system does not decrease the effectiveness of the schools for those students "left behind," but rather may incidentally improve the 
quality of education for those students who remain in public schools. ${ }^{104}$

Another approach would be to distribute a limited number of vouchers on a first-come, first-served basis. Such a limited remedy would adequately distribute resources to avoid the potentially chaotic scenario in which an entire school system breaks down.

\section{Political-QUESTION AND SEPaRATION-OF-PoWERS OBJECTIONS TO VOUCHER REMEDIES}

Voucher opponents often cite the separation-of-powers and political-question doctrines as constraints on courts' power to issue vouchers. These doctrines, however, do not preclude judicial action in the face of constitutional violations. Courts should grant voucher remedies notwithstanding these doctrines; the voucher remedy this Comment proposes is a nonintrusive remedy that respects the separation-of-powers and political-question doctrines.

\section{A. Doctrinal Objections}

The two state courts that have considered requests for private school vouchers both concluded that the separation-of-powers and political-question doctrines precluded such a remedy. ${ }^{105}$ These doctrines, on which the courts in Jenkins and Arviso relied, reflect the judiciary's justifiable hestitation to enter areas traditionally reserved to legislatures. However, these concerns can be duly respected, as long as courts create limited remedies. Courts have deferred to legislatures for years, and legislatures have not responded. Therefore, courts should grant requests for private school vouchers notwithstanding the separation-of-powers and political-question doctrines.

These doctrines present related constraints on the ability of courts to issue private school voucher remedies. ${ }^{106}$ The separation-of-powers principle arises when courts are active in an area that is constitutionally reserved to another branch of government. The political-question doctrine similarly forbids courts to make decisions in areas in which they lack competence either

104 This claim does not rest on the proposition that those students left behind will definitively benefit, but rather that they may or may not benefit. The main point is that those who receive vouchers will benefit, and that their benefit is better than no benefit at all.

105 See Section I.C.

106 Justice Brennan once commented that "[t]he nonjusticiability of a political question is primarily a function of the separation of powers." Baker v Carr, 369 US 186, 210 (1962). 
because there are no sufficiently clear standards or because they lack substantive expertise. These objections are squarely presented when the judiciary attempts to remedy problems in public schools.

The interpretation of the separation-of-powers and politicalquestion doctrines in state constitutional law often differs from their interpretation in federal law. ${ }^{107}$ Several state courts have explicitly rejected a strict separation-of-powers doctrine. ${ }^{108}$ The use of legislative vetoes and advisory opinions in many state systems exemplifies these differences. While the Supreme Court ruled that legislative vetoes are unconstitutional on separationof-powers grounds in INS $v$ Chadh $a{ }^{109}$ state governments are not precluded from employing them. ${ }^{110}$

Similarly, the political-question doctrine is less constraining on courts at the state level. While commentators debate the scope of the political-question doctrine's applicability in state courts, it is clear that, at a minimum, the doctrine is less restrictive in state courts than in federal courts. ${ }^{111}$ Unlike federal courts, state courts routinely handle cases allegedly outside their area of competence, pursuant to their common law powers. While federal courts are constrained by their limited jurisdiction, state courts enjoy a grant of general jurisdiction. This broad scope of state

\footnotetext{
107 It is not uncommon for parallel language in the federal and state constitutions to be read differently. Often it is the federal interpretation that moves the state courts to adopt a variant interpretation. See G. Alan Tarr, Understanding State Constitutions, 65 Temple L Rev 1169, 1190-93 (1992).

${ }^{108}$ See, for example, State $v$ Reed, 248 Kan 792, 811 P2d 1163, 1168 (1991) (holding strict division of executive, legislative, and judicial branches is neither desirable nor intended by the Kansas Constitution); Bartholomew $v$ Schweizer, 217 Conn 671, 587 A2d 1014, 1017-20 (1991) (holding a state statute that allowed counsel to propose suggested damages in the closing argument did not violate the separation-of-powers doctrine given the natural overlap of powers); In re J.J., $142 \mathrm{Ill} 2 \mathrm{~d} 1,566 \mathrm{NE} 2 \mathrm{~d} 1345,1348$ (1991), quoting People $v$ Reiner, $6 \mathrm{Ill}$ 2d 337, 129 NE2d 159 (1955) (stating that a "doctrinaire" interpretation of the constitutional provision regarding separation of powers is impossible because of the difficulty in "classifying particular acts as exclusively legislative, executive,

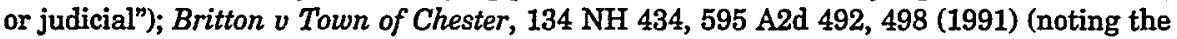
overlap of powers and the inefficiency of a rigid separation-of-powers doctrine). See also Robinson v Cahill, $69 \mathrm{NJ}$ 133, 351 A2d 715, 737 (1975) ("Robinson $I V^{\prime \prime}$ ) (Mountain and Clifford dissenting), quoting Kenneth Culp Davis, Administrative Law Treatise $\$ 1.09$ at 68 (West, 1st ed 1958) ("[T]he true principle that should guide the allocation of power within the general framework is not the principle of separation of the three kinds of power but is the principle of check. ... The danger is not blended power. The danger is unchecked power.").

${ }^{109} 462$ US 919 (1983).

${ }^{110}$ See James A. Gardner, The Failed Discourse of State Constitutionalism, 90 Mich L Rev 761, 809 \& n 206 (1992).

211 See id at 808-09.
} 
courts' jurisdiction allows them to develop the common law and, in effect, invade the legislative sphere without violating the political-question doctrine. ${ }^{12}$

Despite the more lax state standards, some state courts still hold that the political-question and separation-of-powers doctrines bar judicial involvement in education policy. ${ }^{113}$ For instance, these courts maintain that education rights suits are political questions because the power to decide education issues is committed to the legislature, leaving no role for the judicial branch in such matters. ${ }^{114}$ They read the phrase "the legislature shall," in the state education clause, to authorize exclusive domain in this field. ${ }^{115}$

Although state constitutions often grant legislatures the power to make education decisions, they nonetheless impose a duty on the state to provide some minimum, qualitative standard of education, one that is ultimately subject to judicial review. ${ }^{116}$ The language in these provisions is imperative, not discretionary: many of the clauses mandate that the legislature "shall" or "must" create an appropriate education system. These education clauses simultaneously impose a duty on the legislature and grant a substantive education right to students. The Washington

112 Id. Justice Brennan set forth the federal standard for a political question in Baker $v$ Carr, 369 US 186. He stated that a political question exists if there is (1) a "textually demonstrable constitutional commitment of the issue to a coordinate political department"; (2) a "lack of judicially discoverable and manageable standards for resolving it"; (3) "the impossibility of deciding without an initial policy determination of a kind clearly for nonjudicial discretion"; (4) "the impossibility of a court's undertaking independent resolution without expressing lack of the respect due coordinate branches of government"; (5) "an unusual need for unquestioning adherence to a political decision already made"; or (6) "the potentiality of embarrassment from multifarious pronouncements by various departments on one question." Id at 217.

113 See, for example, Danson v Casey, $484 \mathrm{~Pa} 415$, 399 A2d 360, 366-67 (1979) (refraining from defining "thorough and efficient" education as used in the Pennsylvania Constitution, finding that the legislature was simply in a better position to handle education issues).

114 See generally Note, $80 \mathrm{Ky} \mathrm{L} \mathrm{J}$ at 317-21 (cited in note 29).

115 See, for example, Kukor v Grover, 148 Wis 2d 469, 436 NW2d 568 (1989) (refusing to act like a "super-legislature" and deferring to the state legislature regarding issues of education). But see Tennessee Small School Systems, 851 SW2d at 148-52 (rejecting the argument that the constitutionality of the school finance system was nonjusticiable).

116 Seventeen state constitutional education clauses mandate only that the legislature establish a system of free public schools; twenty-two state constitutions require the legislature to provide some qualitative level of education (such as "adequate," "thorough," or "efficient"); six state constitutions set a more demanding standard, calling, for instance, for education to be promoted through "all suitable means"; and finally, four state constitutions make education an important or the most important duty of the state. See Thro, 79 Educ L Rptr at 23-25 \& nn 24-39 (cited in note 1). 
Supreme Court noted the affirmative right created by that state's education clause:

Flowing from this constitutionally imposed "duty" is . . a correspondent "right" ... . Therefore, all children residing within the borders of the State possess a "right," arising from the constitutionally imposed "duty" of the State, to have the State make ample provision for their education. ${ }^{117}$

Thus, the clause both imposes a duty on the legislature and creates a judicially enforceable right to education.

Although no constitutional provision expressly subjects constitutional powers to judicial review, judicial review of a state's success in fulfilling its duties is necessary to preserve the notion of checks and balances upon which state governments are structured. If a state legislature were insulated from any sort of judicial attack, the legislature would assume both legislative and judicial powers: it would have the power to formulate policy, make laws, and later pass on the constitutionality of its own actions.

Education issues, while constitutionally committed to state legislatures, are nonetheless subject to judicial scrutiny given the state courts' role as the final interpreter of state constitutions. ${ }^{118}$ Because state constitututional education clauses, like other state statutes and constitutional provisions, are subject to judicial interpretation, state judiciaries play an important role in determining whether legislatures have fulfilled their constitutional duties. ${ }^{119}$

Given their role as final arbiters of their states' constitutions, state courts retain ample power to issue private school vouchers

117 Seattle School District No. 1 of King County $v$ Washington, 90 Wash 2d 476, 585 P2d 71, 91 (1978) (footnotes omitted). For example, the Washington Constitution declares that the state legislature has a "paramount duty ... to make ample provision for the education of all children residing within its borders." Wash Const, Art IX, § 1.

${ }_{118}$ See McDaniel v Thomas, $248 \mathrm{Ga} 632,285$ SE2d 156, 157 (1981) ("Judicial review of legislative enactments is central to our system of constitutional government and deeply rooted in our history.") (citations omitted). See also Kirby, 777 SW2d at 394 (rejecting contention that school funding issues present a political question not suitable for judicial review); Washakie County School District No. One v Herschler, 606 P2d 310, 318 (Wyo 1980) (holding that school finance case presented "no more a political question than any other challenge to the constitutionality of statutes"). See generally Martin H. Redish, Judicial Review and the "Political Question," $79 \mathrm{Nw}$ U L Rev 1031 (1984-85).

119 See Seattle School District No. 1, 585 P2d at 87 ("[T]he judiciary has the ultimate power and the duty to interpret, construe, and give meaning to words, sections, and articles of the constitution. It is emphatically the province and duty of the judicial department to say what the law is.") (citations omitted). 
and thus check the unconstitutional actions of coequal branches of government. ${ }^{120}$ This power to check legislative action enables courts to provide a remedy for the violation of a state constitutional right to education when other branches of government have failed. ${ }^{121}$ If the other branches have not satisfactorily responded to court decisions holding that public schools are constitutionally inadequate, the courts must intervene. Notwithstanding the political-question and separation-of-powers doctrines, once courts have invited legislatures to act and they have refused, courts should fashion narrowly tailored remedies to protect constitutional rights. If courts do not act, they concede that the state's constitution "embodies rights in a vacuum, existing only on paper."122

Some courts have also held educational challenges to be nonjusticiable political questions because the abstract language in the state constitutional education clauses, such as "adequate," "efficient," or "effective" education, lacks justiciable standards. ${ }^{123}$ However, as previously noted, state courts have fashioned justiciable standards to adjudicate education disputes by reading specific requirements into the education clauses of state constitutions. ${ }^{124}$ Courts in New Jersey, West Virginia, Texas, Kentucky, and Washington have overcome concerns of justiciable standards by interpreting the constitutional language in terms of concrete requirements.

Despite concerns about the political-question and separationof-powers doctrines, state courts have acted to protect education rights throughout the country. There remains, however, the need to fashion remedies for the violations of these rights. State courts rejected these political-question and separation-of-powers argu-

120 See, for example, Robinson v Cahill, 69 NJ 449, 355 A2d 129, 139-40 (1976) ("Robinson $V^{\prime \prime}$ ) (Hughes concurring) (observing that state constitutions commit educational matters to legislative and executive branches, and if these branches fail to fulfill such duties in a constitutional manner, "the court too must accept its continuing constitutional responsibility ... for overview . . of compliance with the constitutional imperativen).

${ }_{121}$ See Southern Burlington County NAACP $v$ Tounship of Mount Laurel, 92 NJ 158, 456 A2d 390, 417-18 (1983) ("In the absence of adequate legislative and executive help, we must give meaning to the constitutional doctrine in the cases before us through our own devices, even if they are relatively less suitable.").

${ }_{122}$ Robinson $I V, 351$ A2d at 720, quoting Cooper v Nutley Sun Printing Co., Inc., 36 NJ 189, 175 A2d 639, 643 (1961).

${ }^{123}$ See, for example, Kirby $v$ Edgewood Independent School District, 761 SW2d 859, 867 (Tex App 1988), rev'd, 777 SW2d 391 (Tex 1989); Danson v Casey, 382 A2d 1238, 1246 (Pa Commw Ct 1978), aff'd, 399 A2d 360 (Pa 1979). See also Pauley $v$ Kelly, 255 SE2d 859,898 (W Va 1979) (Neely dissenting).

124 See text accompanying notes 25-26. 
ments when they held that school systems were constitutionally inadequate in the first place. The remedial phase of these cases should present no additional difficulties given that the courts have already found the issue of education rights to be justiciable.

B. Judicial Activism in the Face of Legislative Inaction

Furthermore, the United States Supreme Court and state supreme courts have endorsed judicial activism in cases where state officials are unresponsive to constitutional violations. In Swann v Charlotte-Mecklenburg Board of Education, a desegregation case, the United States Supreme Court held:

If school authorities fail in their affirmative obligations ... judicial authority may be invoked. Once a right and a violation have been shown, the scope of a district court's equitable powers to remedy past wrongs is broad, for breadth and flexibility are inherent in equitable remedies. $^{125}$

In Southern Burlington County NAACP $v$ Township of Mount Laurel, ${ }^{126}$ the New Jersey Supreme Court displayed a similar inclination toward judicial activism, providing low-income housing opportunities in Mount Laurel despite legislative inaction. The court said that it acted "first and foremost because the Constitution of our State requires protection of the interests involved and because the Legislature has not protected them.... [E]nforcement of constitutional rights cannot await a supporting political consensus. ... That is our duty. ... [W]e do enforce the Constitution."127 Similarly, state courts have recognized violations of the state constitutional right to education, and they are now under a similar obligation to fashion remedies.

Furthermore, the need for judicial activism is greater in certain contexts. The Supreme Court has held that courts should be particularly willing to take an activist role to protect the rights of underrepresented groups. ${ }^{128}$ Courts need to be espe-

125402 US $1,15(1970)$.

${ }^{126} 92$ NJ 158, 456 A2d 390 (1983).

127 Id at 417 .

${ }_{123}$ See United States $v$ Carolene Products Co., 304 US 144, 152-53 n 4 (1938) (suggesting that the impediments to the political process's aim of properly representing minorities may call for increased judicial activism); John Hart Ely, Democracy and Distrust: A Theory of Judicial Review 84 (Harvard, 1980) (arguing that judicial review can guard against malfunctions of the political process); J. Skelly Wright, The Role of the Supreme Court in a Democratic Society-Judicial Activism or Restraint?, 54 Cornell L Rev 1, 9 
cially active when enforcing education rights because the victims of such violations are often politically powerless. Typically, plaintiffs in education reform cases come from low-income backgrounds and have little political power. They usually cannot amass the necessary resources to wage effective lobbying campaigns before their legislatures, and their interests will therefore often be underrepresented in the political process.

\section{Vouchers Are Less Offensive than Alternative Remedies}

Private school vouchers are less offensive to the separationof-powers and political-question doctrines than the remedial legislative orders that many courts now issue in suits brought under state constitutional education provisions. In several states, courts have mandated that legislatures fashion an appropriate remedy and have provided rigid guidelines for doing so, despite serious separation-of-powers and political-question concerns. In Abbott $v$ Burke, ${ }^{129}$ for example, the New Jersey Supreme Court did not directly raise taxes or sponsor education legislation, but it did become a silent participant in these legislative functions. The court ordered the legislature to come up with an education plan that provides educational equality. ${ }^{130}$ Such a plan is not feasible without significant tax hikes and spending reallocation. These acts are largely judicially created, despite being carried out by the legislature. These acts present formidable separation-of-powers and political-question concerns, much greater than those raised by private school vouchers. The acceptance of these legislative orders strongly suggests the validity of private school vouchers as well.

Additionally, the United States Supreme Court recently condoned judicial involvement in state funding issues in Missouri $v$ Jenkins, when it upheld a federal court's imposition of state taxes as a remedy for school segregation. ${ }^{131}$ The Court affirmed lower court decisions that had instituted a remedial plan and then raised taxes to finance it. Thus, courts are not absolutely barred from adjudicating issues that directly affect the state treasury. In the face of constitutional violations, the court may be

(1968) ("If substantial rights are at stake which the legislative process cannot or will not vindicate, the task of doing so unfortunately, but inevitably, passes to the courts.").

$129119 \mathrm{NJ} 287,575$ A2d 359 (1990).

130 Id at $408-11$.

131495 US 33, 52-58 (1990). 
compelled to order the use of state funds to effectuate its orders. State courts have in the past controlled state funds. ${ }^{132}$

\section{CONCLUSION}

Education in the United States remains troubled. While teachers, administrators, and politicians debate the merits of various education reform proposals, students endure overcrowded classrooms, dilapidated buildings, and antiquated textbooks. The national discussion over education has generated creative ideas: teaching advances, computer technology, for-profit schools, and more equitable taxation. Each of these proposals, however, requires time for both development and implementation. Unfortunately, students currently attending inadequate schools cannot afford to wait years for reforms to take effect. State courts must fashion remedies for violations of constitutional education rights that are effective immediately. Private school vouchers provide just such a means. Courts have recognized the fundamental right to education under state constitutions for two decades; however, enforcement of that right has been slow in coming. The prolonged struggles between state courts and state legislatures over education reform have perpetuated substandard educational opportunities that violate students' constitutional rights. Narrowly tailored vouchers, issued only to students in constitutionally inadequate schools, provide an effective and timely solution. Courts have the equitable powers to impose a voucher remedy; they need to seriously consider this option, lest they forgo their duties and fail to protect the education rights of students. 
